\title{
Investigation of athlete high school students' moral decision-making attitudes in terms of sport variables
}

Authors' Contribution: A Study Design

B Data Collection C Statistical Analysis D Data Interpretation E Manuscript Preparation

F Literature Search G Funds Collection

\author{
Oğuz Özbek ${ }^{1 \text { ACDE}}$, Umut Nalbant ${ }^{2}$ ABDE \\ ${ }^{1}$ Department of Sports Management, Faculty of Sports Sciences, Ankara University \\ Ankara, Turkey \\ 2 Department of Sports Sciences, Faculty of Health Sciences, East Mediterranean \\ University, Gazimağusa, Northern Cyprus
}

\section{abstract}

Background: Sports activities are performed in accordance with moral values and principles. The purpose of this research is to examine the decision-making attitudes of young sports students based on age, gender, license status, and sports branch type.

Material and methods:

The "Moral Decision-Making Scale in Youth Sports" developed to evaluate the moral decision-making attitudes of young athletes was used as a data collection tool in this research. A five-point Likert scale was used to evaluate the scale items.

Results: The athletes' views regarding moral decision-making attitudes were found to be for the Acceptance of Cheating dimension for the Acceptance of Gamesmanship dimension; and for the Keep Winning in Proportion dimension. It was determined that there was a significant difference in the student athletes' moral decision-making attitudes depending on gender, the type of sports played and being a certified athlete.

Conclusions: Sports fields are the places where young athletes exhibit their skills and abilities in competitions. In these competitions, it should be emphasized to young athletes that respecting the values of the sport and following the rules is more important than winning and that they should stay away from negative behaviors such as cheating or gamesmanship.

Key words: cheating, gamesmanship, moral decision-making, youth sports.

\section{article details}

Article statistics:

Full-text PDF:

Copyright

Indexation:

Funding:

Conflict of interests:

Corresponding author:

Open Access License:

Word count: 2,988; Tables: 5; Figures: 0; References: 35

Received: December 2020; Accepted: May 2021; Published: September 2021

http://www.balticsportscience.com

(c) Gdansk University of Physical Education and Sport, Poland

Celdes, Clarivate Analytics Emerging Sources Citation Index (ESCI), CNKI Scholar (China National Knowledge Infrastructure), CNPIEC, DOAJ, EBSCO - Central \& Eastern European Academic Source, EBSCO - SPORTDiscus, EBSCO Discovery Service, Google Scholar, Index Copernicus, J-Gate, Naviga (Softweco, Primo Central (ExLibris), ProQuest - Family Health, ProQuest - Health \& Medical Complete, ProQuest - Illustrata: Health Sciences, ProQuest Nursing \& Allied Health Source, Summon (Serials Solutions/ProQuest, TDOne (TDNet), Ulrich's Periodicals Directory/ ulrichsweb, WorldCat (OCLC)

This research received no specific grant from any funding agency in the public, commercial, or not-for-profit sectors. Authors have declared that no competing interest exists.

Oğuz ÖZBEK, Ankara University Faculty of Sports Sciences, Department of Sports Management, Ankara, Turkey; e-mail: oozbek@sports.ankara.edu.tr

This is an open access article distributed under the terms of the Creative Commons Attribution-Non-Commercial-NoDerivatives 4.0 International (https://creativecommons.org/licenses/by-nc-nd/4.0/), which permits use, distribution and reproduction in any medium, provided the original work is properly cited, the use is non-commercial and is otherwise in compliance with the license. 


\section{INTRODUCTION}

Sports is an important activity that contributes to an individual's mental and social development. It is also a convenient means of gaining such values as honesty, respectfulness, tolerance, cooperation and fair-play spirit which are necessary for personal and social growth. Sports activities are performed in accordance with moral rules and values. In that regard, young individuals, in particular, are able to earn such moral rules and values while doing sports activities. Moral conduct in sports deals with such behavior related to fair play, respecting the rules, respecting the opponents and accepting defeat as a whole [1]. While shooting the ball out when an opponent gets injured is interpreted as fair play, provoking the opponent or faking an injury are seen as the kind of behavior that does not fit sports ethics [2].

It has been determined that the factors affecting moral behavior in sports are environmental influences in addition to personality traits [3, 4]. Furthermore, there is research demonstrating that there is an inverse relationship between being overly passionate about winning in sports and acting in compliance with sports ethics [5]. Excessive desire for winning in sports leads to immoral behavior that is against the rules of the competition [6]. Doing sports in leisure time is among the most popular activities among both male and female students [7]. In order to prevent certain behaviors in sports, such as aggression, rule-breaking, cheating in a game, young athletes must learn the concept of ethics in sports in the best manner possible [1]. In addition to contributing to an individual's personal and social growth, sports also play an important role in learning moral values [2]. In this context, the role of physical education teachers and coaches in the moral education of young athletes comes to the fore. In a study examining the views of coaches working with young athletes, it was seen that the personal role of coaches in the moral education of athletes was of great importance [8].

Cheating means secretly breaking a rule upon which everyone has agreed [9]. Gamesmanship means going any lengths at all costs to win a competition and to try to succeed by breaking the rules [10]. Coaches play a significant part in the development of athletes' personalities [11]. If a coach has a high level of self-efficacy, this will reflect on the athletes and have a positive impact on their personal moral growth and athletic proficiency as well as on individual and team achievements [12]. It was determined that in the case of establishing an ego-oriented atmosphere in coach-athlete relationships at the competition and training fields rather than a task-oriented atmosphere, there will be a high level of cheating and gamesmanship [13]. There are studies suggesting that individuals with an antisocial personality are more prone to such behavior as cheating and resorting to violence in the competition and that there is a direct relationship between moral conduct and proper behavior $[3,14]$. In a study conducted with young tennis athletes, it was observed that there was a relationship between the anti-social attitudes of the athletes and their cheating behaviors during the match, and there was a direct link between moral attitude and actual behavior [15]. In order to understand how moral decision making takes place, it is necessary to explain the relevant social factors, decision-making processes, and the relationship of moral decisions to behavior. Due to the complexity of the moral decisionmaking process, there are different theories put forward on this subject [16].

In this study, the emergence of moral behavior in young athletes was tried to be explained through self-determination theory. Self-determination is the determination of an individual's decisions based on his own personal beliefs and value judgments. The individual decides how to behave not by external forces, pressures, or rewards, but by his own beliefs and values [17]. The purpose of self-determination theory is to identify the conditions that ensure healthy development of individuals and to clearly define the factors that are effective in the well-being process [18]. According to the self-determination theory, humans 
are essentially organisms with a coherent self, tendencies for psychological development, and striving to overcome existing obstacles [19].

Psychological needs, such as autonomy, competence, and relatedness, are at the heart of the self-determination theory. The satisfaction of these basic needs is essential for individuals' growth, integration, development and mental health [18]. Autonomy refers to the individual's being under his own control and approving his own behavior [20]. The need for competence refers to an individual's desire to influence his / her environment well and his / her capacity to interact effectively with the environment [21]. The need to be associated refers to the individual's desire to be in contact with his social environment, to feel belonging and to establish a relationship [18]. The prosocial and antisocial behaviors of young athletes take place under their own control, with the aim of influencing the environment and communicating. With sports training, young athletes should be taught ethical behavior, and instead of catching young athletes violating the moral rules, it should be a priority to give them examples of behavior in accordance with sports ethics [22]. Adolescents come across as an important social problem of peer bullying experienced by individuals [23]. It is possible to eliminate such antisocial behaviors with sports education. In a study conducted with young athletes, it was found that the self-determination theory could be valid in explaining negative behaviors in sports [24]. Young athletes decide to cheat in the competition or to act in accordance with the fair play rules, based on their own beliefs and values. According to the self-determination theory, the approval of the young athletes' positive behaviors in the field of the competition by the coach and his family, and the reaction to their negative behaviors by the same environment will lead him to repeat the approved behaviors and prevent negative behaviors.

The "Moral Decision-Making Scale in Youth Sports" was developed to assess young athletes' moral decision-making attitudes in sports activities [25]. The scale consists of statements regarding the moral attitudes of athletes during competition with respect to sub-dimensions such as maintaining fair play, embracing cheating, embracing gamesmanship [26]. In this study, it has been hypothesized that the moral decision-making attitudes of young athletes will differ according to their age, licensed athletes and sports branches. The purpose of this research is to examine the moral decision-making attitudes of young student athletes on the basis of age, gender, license status, and sports branch type.

\section{MATERIAL AND METHODS}

\section{RESEARCH DESIGN}

In the research, an unrelated scanning model, one of the quantitative method models, was used. As the data collection tool, the research made use of the "Moral DecisionMaking Scale in Youth Sports" (AMDYSQ-2) developed to assess the moral decisionmaking attitudes of young athletes [26]. The Scale was adapted to the Turkish language by Gürpınar [27, 28]. The validity of the scale was analyzed by using explanatory factor analysis, and the three-dimensional structure as is in the original scale was verified. The scale comprises 15 items including sub-dimensions such as embracing cheating, embracing gamesmanship and maintaining fair play. While three of the items on the scale have positive connotations, twelve of the items have negative connotations. The Cronbach's Alpha internal consistency coefficient was found to be 0.82 for the overall scale; with respect to the sub-dimensions, the coefficient was 0.83 for embracing cheating, 0.72 for embracing gamesmanship and 0.52 for maintaining fair play. The five-point Likert-type scale was used in the evaluation of the scale items (strongly disagree $=1$ and strongly agree $=5$ ). While higher points on the scale represent a positive moral decision-making attitude, lower points demonstrate a negative moral decision-making attitude. Permission was obtained by the author via e-mail to use the Turkish version of the scale. 


\section{PARTICIPANTS}

The research group comprises 405 student athletes between the ages of 15-18 who currently receive education at high schools in the Northern Cyprus and who have played sports as certified athletes in the school team or in any sports club. The convenience sampling method was used in the sample selection. 298 (73.6\%) of the participants are male, and 107 (26.4\%) are female. 142 of the participants (35.1\%) are 15-year-olds, 70 (17.3\%) are 16-year-olds, 70 (17.3\%) are 17-year-olds and $123(30.4 \%)$ are 18-year-olds. $164(40.5 \%)$ of the participants hold a sports club license, $64(15.8 \%)$ hold a college sports license, and 177 (43.7\%) hold both sports club and college sports licenses.

The internal consistency coefficient for the data was found to be 0.84 in the overall scale and 0.50 for the maintaining fair play sub-dimension, 0.88 for the embracing cheating sub-dimension and 0.77 for the embracing gamesmanship sub-dimension. The skewness and kurtosis values were referred to in order to examine whether the data was distributed normally (Table 1).

Table 1. Mean, skewness and kurtosis values for the data

\begin{tabular}{cccc}
\hline Sub-dimensions & $\overline{\mathrm{x}} \pm \mathrm{SD}$ & Skewness & Kurtosis \\
\hline Maintaining fair play & $3.80 \pm 0.87$ & -0.44 & -0.29 \\
Embracing cheating & $4.11 \pm 0.93$ & -1.08 & 0.50 \\
Embracing gamesmanship & $2.95 \pm 0.92$ & 0.05 & -0.64 \\
\hline
\end{tabular}

\section{STATISTICAL ANALYSIS}

The data was accepted as having normal distribution since the skewness and kurtosis values ranged between +1 and -1 . Groups of two were tested with the t-test, and groups of more than two items were tested using one-way analysis of variance. In the cases where variance was determined among the groups as a result of one-way analysis of variance, the Scheffe test was used to identify the variant group. The significance level was adopted at $p<0.05$. Statistical analysis was carried out with the SPSS 21 software program.

\section{RESULTS}

As seen in Table 1 above, young athletes' views on their moral decision-making attitudes are $(\overline{\mathrm{x}}=4.11 ; \mathrm{s}=0.93 \pm)$ in the embracing cheating sub-dimension, $(\overline{\mathrm{x}}=3,95 ; \mathrm{s}=0.92 \pm)$ in the embracing gamesmanship sub-dimension and $(\overline{\mathrm{x}}=3.80 ; \mathrm{s}=0.87 \pm)$ in the maintaining fair play sub-dimension. A significant difference was not established as a result of the t-test conducted between the views of female and male athletes with respect to the maintaining fair play sub-dimension $[t(403)=1.61, p>.05]$. Namely, there was no difference between the attitudes of female and male athletes in the maintaining fair play sub-dimension (Table 2 ).

Table 2. T-test analysis results for gender-based views

\begin{tabular}{lccccc}
\hline Dimensions & Gender & $\mathrm{N}$ & $\overline{\mathrm{x}} \pm \mathrm{SD}$ & $\mathrm{t}$ & $\mathrm{p} *$ \\
\hline \multirow{2}{*}{ Maintaining fair play } & Female & 107 & $3.92 \pm 0.81$ & \multirow{2}{*}{0.61} & 0.10 \\
\hline \multirow{2}{*}{ Embracing cheating } & Male & 298 & $3.76 \pm 0.88$ & & \multirow{2}{*}{$0.00^{*}$} \\
\hline \multirow{2}{*}{ Embracing gamesmanship } & Female & 107 & $4.30 \pm 0.81$ & 2.61 & $0.00 *$ \\
\hline
\end{tabular}

$* p<0.05$ 
A significant difference was identified as a result of the t-test analysis conducted between the views of female and male athletes in the embracing cheating sub-dimension $[t(403)=2.61$, $\mathrm{p}<.05]$. It was determined that female student athletes had a more positive attitude with regard to embracing cheating than male student athletes $[t(403)=3.27, p<.05]$. Female athletes had a more positive attitude with regard to embracing gamesmanship than male athletes, as well.

As seen in Table 3, a significant difference was not established as a result of one-way analysis of variance performed on the participants' views in the maintaining fair play dimension based on the participants' license status $[F(2 ; 402)=0.080, p>0.05]$. A significant difference was identified as a result of the one-way analysis of variance performed on the participants' views on the embracing cheating dimension based on their license status $[F(2 ; 402)=6.18, p<0.05]$. The Scheffe test which was performed to identify the variant group demonstrated that the athletes holding a college sports license and the athletes holding both sports club and school sports licenses had a more positive attitude to the embracing cheating dimension.

With respect to the embracing gamesmanship dimension, one-way analysis of variance performed on the participants' views based on their license status did not show a significant difference $[F(2 ; 402)=10.8, p<0.05]$. The Scheffe test which was performed to identify the variant group demonstrated that the athletes holding a college sports license had a more positive attitude in the embracing gamesmanship dimension than the athletes holding a sports club license and the athletes holding both sports club and college sports licenses.

Table 3. One-way analysis of variance results for participant views based on license status

\begin{tabular}{lcccccc}
\hline Dimensions & License Status & $\mathrm{n}$ & $\overline{\mathrm{x}} \pm \mathrm{SD}$ & $\mathrm{F}$ & $\mathrm{p} *$ & Difference (Scheffe) \\
\hline $\begin{array}{l}\text { Maintaining fair } \\
\text { play }\end{array}$ & Sports Club License & 164 & $3.81 \pm 0.882$ & & & \\
& School license & 64 & $3.83 \pm 0.868$ & 0.08 & 0.92 & - \\
\hline $\begin{array}{l}\text { Embracing } \\
\text { cheating }\end{array}$ & Sports club and School License & 177 & $3.78 \pm 0.867$ & & & \\
\hline Sports Club License & 164 & $3.93 \pm 1.019$ & & $\begin{array}{l}\text { School license. } \\
\text { School and Sports } \\
\text { Club License> }\end{array}$ \\
$\begin{array}{l}\text { Embracing } \\
\text { gamesmanship }\end{array}$ & Sports club and School License & 177 & $4.19 \pm 0.883$ & Sports Club License \\
\hline
\end{tabular}

$* p<0.05$

As evident in Table 4, the t-test analysis performed on the views of team and individual athletes for the maintaining fair play dimension did not indicate a significant difference $[t(403)=0.948, p>0.05]$. A difference was not identified between the attitudes of athletes team and individual sports concerning the maintaining fair play dimension $[t(403)=4.83$ $\mathrm{p}<0.05]$. No difference was identified between the attitudes of team athletes and individual athletes in the maintaining fair play dimension. The t-test analysis performed on the views of team and individual athletes concerning the embracing cheating dimension resulted in a significant difference [t(403) $=4.83 \mathrm{p}<0.05]$. It was established that individual athletes had a more positive attitude than team athletes concerning the embracing cheating dimension.

As a result of the t-test analysis performed on the views of team and individual athletes concerning embracing gamesmanship, a significantly difference was identified $[t(403)=4.93$ $\mathrm{p}<0.05]$. It was established that individual athletes had a more positive attitude than team athletes with respect to the embracing gamesmanship dimension. 
Table 4. T-test analysis results for participant views based on the type of sports

\begin{tabular}{lccccc} 
Dimensions & Branch & $\mathrm{n}$ & $\overline{\mathrm{x}} \pm \mathrm{SD}$ & $\mathrm{t}$ & $\mathrm{p} *$ \\
\hline \multirow{2}{*}{ Maintaining fair play } & Team Sports & 306 & $3.78 \pm 0.825$ & .948 & 0.34 \\
& Individual Sports & 99 & $3.88 \pm 1.00$ & & \multirow{2}{*}{$0.01^{*}$} \\
\hline \multirow{2}{*}{ Embracing cheating } & Team Sports & 306 & $4.00 \pm 0.95$ & \multirow{2}{*}{4.83} & $0.01^{*}$ \\
\hline \multirow{2}{*}{ Embracing gamesmanship } & Individual Sports & 99 & $4.46 \pm 0.78$ & \multirow{2}{*}{4.93} & \\
\hline
\end{tabular}

$* p<0.05$

As seen in Table 5, no significant difference was identified following one-way analysis of variance performed on the views of young athletes based on age in the maintaining fair play dimension $[\mathrm{F}(3 ; 401)=2.05, \mathrm{p}>.05]$, the embracing cheating dimension $[\mathrm{F}(3$; $401)=1.17, \mathrm{p}>.05]$, and the embracing gamesmanship dimension $[\mathrm{F}(3 ; 412)=2.29, \mathrm{p}>.05]$. It was demonstrated that there was no difference in the moral decision-making attitudes of young athletes with respect to embracing cheating, embracing gamesmanship and maintaining fair play on the basis of age.

Table 5. One-way analysis of variance of views based on age

\begin{tabular}{|c|c|c|c|c|c|}
\hline Dimensions & Age & $n$ & $\bar{x} \pm S D$ & $\mathrm{~F}$ & $\mathrm{p}$ \\
\hline \multirow{4}{*}{ Maintaining fair play } & 15 years & 142 & $3.82 \pm 0.836$ & \multirow{4}{*}{2.05} & \multirow{4}{*}{0.10} \\
\hline & 16 years & 70 & $3.98 \pm 0.904$ & & \\
\hline & 17 years & 70 & $3.83 \pm 0.829$ & & \\
\hline & 18 years & 123 & $3.66 \pm 0.905$ & & \\
\hline \multirow{4}{*}{ Embracing cheating } & 15 years & 142 & $4.14 \pm 0.886$ & \multirow{4}{*}{1.17} & \multirow{4}{*}{0.32} \\
\hline & 16 years & 70 & $4.26 \pm 0.859$ & & \\
\hline & 17 years & 70 & $4.07 \pm 0.945$ & & \\
\hline & 18 years & 123 & $4.01 \pm 1.022$ & & \\
\hline \multirow{4}{*}{ Embracing gamesmanship } & 15 years & 142 & $3.02 \pm 0.884$ & \multirow{4}{*}{2.29} & \multirow{4}{*}{0.07} \\
\hline & 16 years & 70 & $3.11 \pm 1.013$ & & \\
\hline & 17 years & 70 & $2.94 \pm 0.982$ & & \\
\hline & 18 years & 123 & $2.79 \pm 0.866$ & & \\
\hline
\end{tabular}

$* p<0.05$

\section{DISCUSSION}

This research examines the moral decision-making attitudes of high school athletes according to specific variables, such as age, gender, license status, and the type of sports. The primary objective of this research is to evaluate moral attitudes based on gender differences. The research demonstrated that embracing cheating and gamesmanship was more common in male athletes than in female athletes. In parallel with this result, there has been other research establishing that the level of acceptance of cheating and gamesmanship is higher in males than in females [29,30]. Thus, it is generally asserted that male athletes are more inclined to exhibit such behavior as violating the rules and cheating in sports games [31]. A study conducted with young basketball players showed that female players were more accepting of gamesmanship and cheating than male players [2]. Whereas female athletes mostly prefer to play sports in accordance with the established rules [32], male athletes are more prone to cheating than female athletes. In 
the study of Bronikowska, Korcz, and Bronikowski [33], it was found that female athletes have higher moral competence than male athletes in professional youth sports. In another study, it was observed that sports training for many years positively affected the moral development of male students [34].

Athletes holding sports club and school licenses embrace cheating and gamesmanship more than athletes who are only holders of a school sports license. The fact that school teams prioritize athletic values and athletes' health over winning games whereas sports clubs urge for competitiveness and winning may incline student athletes to further embrace cheating in sports. It was identified that individual athletes embrace cheating and gamesmanship more than team athletes. In contrast to this result [25], it was observed that embracing cheating and gamesmanship was more frequent in team athletes than in individual athletes. It was seen that there was no difference among the moral decisionmaking attitudes of young athletes concerning embracing gamesmanship and maintaining fair play on the basis of age. In contrast to this result, it was determined that acceptance of cheating and gamesmanship was more frequent in young athletes who are relatively older in comparison to relatively younger athletes [1, 32, 35].

\section{CONCLUSIONS}

As a conclusion, the moral decision-making attitudes of student athletes were seen to differ based on gender, type of sports and the status of being a certified athlete. Students must be sensitized in order to prevent unsportsmanlike behavior on the playfield, which is a place for young athletes to exhibit their skills and abilities. It must be accentuated to young athletes during sports competitions that respecting athletic values and obeying the rules of the game is more important than winning, and that they must avoid negative behaviors, such as cheating and gamesmanship. The perception adopted by student athletes must be one that is compliant with sports ethics. On the other hand, the fact that the sample group of this research only comprises high school students in the Northern Cyprus may be viewed as a limiting quality; therefore, a comparative (cross-cultural) research can be done on the subject of moral decision-making attitudes of young athletes by involving high school students from various cultures.

\section{REFERENCES}

[1] Kaye MP, Ward KP. Participant-related differences in high school athletes' moral behavior. Athletic Insight: Online J Sport Psychol. 2010;12(1):1-17.

[2] Ponseti FJ, Cantallops J, Muntaner-Ma A. Fairplay, cheating and gamesmanship in young basketball teams. J Phys Educ Health, 2016;5(8):29-33.

[3] Lucidi F, Zelli A, Mallia L, Nicolais G, Lazuras L, Hagger MS. Moral attitudes predict cheating and gamesmanship behaviors among competitive tennis players. Front Psychol. 2017;8:571. https://doi.org/10.3389/fpsyg.2017.00571

[4] Ntoumanis N, Standage. Morality in Sport: A Self-Determination Theory Perspective. J Appl Psychol. 2009;21:365380. https://doi.org/10.1080/10413200903036040

[5] Bureau JS, Vallerand RJ, Ntoumanis N, Lafreniere MAK. On passion and moral behaviour in achievement settings. The mediating role of pride. Motiv Emot, 2012;37:121-133. https://doi.org/10.1007/s11031-012-9292-7

[6] Tanrıverdi H. Spor ahlakı ve şiddet [Sport ethics and violence]. J Acad Soc Sci Stud. 2012;5(8):1071-1093. Turkish. https://doi.org/10.9761/jasss_361

[7] Ntoumanis N, Taylor IM, Thøgersen-Ntoumani C. A longitudinal examination of coach and peer motivational climates in youth sport: Implications for moral attitudes, well-being, and behavioral investment. Develop Psychol. 2012;48: 213-223. https://doi.org/10.1037/a0024934

[8] Sukys S, Dargene Z, Karanauskiene D. Qualitative investigation of coaches' perspectives on moral education in sport. Balt J Sport Health Sci. 2017;4(107):46-56. https://doi.org/10.33607/bjshs.v4i107.39

[9] Loland S. The Varieties of cheating-comments on ethical analyses in sport. Sport Society. 2005;8(1):11-26. https:// doi.org/10.1080/1743043052000316597

[10] Lumpkin A, Stoll K, Beller JM. Sport ethics: Applications for fair play. 3rd ed. McGrawHill; 2003.

[11] Luke N. Winning by deemphasizing winning: Establishing climates for moral development in sports. Sport J. 2014; 31(20):1. 
[12] Koçak ÇV, Güven Ö. Voleybol antrenörü mesleki öz yeterlik ölçeği geçerlik ve güvenirlik çalışması [The validity and reliability study of professional self-efficacy scale for volleyball coach]. Spormetre. 2018;16(2);162-177. Turkish https://doi.org/10.1501/Sporm_0000000363.

[13] Palou P, Ponseti FJ, Cruz J, Vidal J, Cantallops J, Borràs PA, Garcia-Mas A. Acceptance of gamesmanship and cheating in young competitive athletes in relation to the motivational climate generated by parents and coaches. Percept Motor Skill. 2013;117(1):290-303. https://doi.org/10.2466/10.30.PMS.117x14z9

[14] Yılmaz A, Esentürk OK, İlhan EL. Ortaokul öğrencilerinin ahlaki gelişimleri açısından sportmenlik yönelimleri [Sportsmanship tendency in terms of moral development of middle school students]. J Human Sci. 2017;14(4):49694988. Turkish. https://doi.org/10.14687/jhs.v14i4.4869

[15] Lucidi F, Zelli A, Mallia L, Nicolais G, Lazuras L, Hagger M. Moral attitudes predict cheating and gamesmanship behaviors among competitive tennis players. Front Psychol. 2017;8:571. https://doi.org/10.3389/fpsyg.2017.00571

[16] Garrigana B, Adlam LRA, Langdon PE. Moral decision-making and moral development: Toward an integrative framework Beverley. Develop Rev. 2018;49:80-100. https://doi.org/10.1016/j.dr.2018.06.001

[17] Deci E, Connell J, Ryan R. Self-determination in a Work Organization. J Appl Psychol. 1989;74(4):580-590. https:// doi.org/10.1037/0021-9010.74.4.580

[18] Ryan R, Deci EL. Self-determination theory and the facilitation of intrinsic motivation, social development and wellbeing. Am Psychol. 2000;55(1):68-79. https://doi.org/10.1037/0003-066X.55.1.68

[19] Deci EL, Ryan RM. Overview of self-determination theory: An organismic dialectical perspective. Handbook of SelfDetermination Research. University of Rochester Press; 2002.

[20] Çankaya ZC. Özerklik desteği, temel psikolojik ihtiyaçların doyumu ve öznel iyi olma: Özbelirleme kuramı. [Autonomy support, satisfaction of basic psychological needs and well-being: Self-Determination theory]. Türk Psikolojik Danışma ve Rehberlik Dergisi. 2016;4(31):23-31.Turkish.

[21] Deci EL, Ryan R. Intrinsic Motivation and Self-Determination in Human Behavior. New York: Plenum Press; 1985. https://doi.org/10.1007/978-1-4899-2271-7

[22] Harvey S, Kirk D, O'Donovan TM. Sport education as a pedagogical application for ethical development in physical education and youth sport, Sport, Educ Society, 2014;19(1):41-62. https://doi.org/10.1080/13573322.2011.624594

[23] Boucharda K, Forsbergb C, Smith DJ, Thornberg R. Showing friendship, fighting back, and getting even: resisting bullying victimization within adolescent girls' friendships. J Youth Stud. 2018;21(9):1141-1158. https://doi.org/10. 1080/13676261.2018.1450970

[24] Mallia L, Lucidi F, Zelli A, Chirico A, Hagger SM. Predicting moral attitudes and antisocial behavior in young team sport athletes: A self-determination theory perspective. J Appl Soc Psychol. 2019;49:249-263. https://doi.org/10.1111/ jasp.12581

[25] Lee MJ, Whitehead J, Ntoumanis N. Development of the attitudes to moral decision-making in youth sport questionnaire (AMDYSQ). Psychol Sport Exerc. 2007;8(3):369-392. https://doi.org/10.1016/j.psychsport.2006.12.002

[26] Whitehead J, Ntoumanis N. İlerleyen zamanlarda AMDYSQ'nun kullanılması ve AMDYSQ-2'nin geliștirilmesi [Values in youth sport and physical education] (Whitehead J, Telfer H, Lambert J. Ed.), Altyapı Sporlarında ve Beden Eğitiminde Değerler (Transleted Gürpınar, B). [Values in youth sport and physical education] Ankara: Nobel; $2016 ; 230-237$. Turkish.

[27] Gürpınar, B. Genç sporcuların ahlaki karar verme tutumları ölçeği 2 (AMDYSQ-2): Türkçe'ye Uyarlama Çalışması [mora decision making attitudes of young athletes scale 2 (AMDYSQ-2): Adaptation to Turkish Study.] 13th International Sport Science Congress, Konya, Turkey, 2014 Nov. Turkish.

[28] Gürpınar B. adaptation of the attitudes to moral decision-making in youth sport questionnaire-2 into Turkish culture: A validity and reliability study. Pamukkale J Sport Sci. 2016;7(2):27-39.

[29] Guivernau M. Duda JL. Moral atmosphere and athletic aggressive tendencies in young soccer players. J Moral Educ. 2002;31(1):67-85. https://doi.org/10.1080/03057240120111445

[30] Atalay M. moral decision making attitudes of the student athletes studying at universities in Turkey. J Acad Social Sci. 2016;4(31):53-66. https://doi.org/10.16992/ASOS.1331

[31] Weiss MR, Bredemeier BJL. Moral development in sport. Exerc Sport Sci Rev. 1990;18(1): 331-378. https://doi. org/10.1249/00003677-199001000-00015

[32] Gürpınar B. Sporcu ortaokul ve lise öğrencilerinin spora ait değişkenler açısından ahlaki karar alma tutumları [Attitudes to moral decision making of the student athletes in secondary and high school level according to sport variables]. Educ Sci. 2014;(39176:413-424. Turkish. https://doi.org/10.15390/EB.2014.3645

[33] Bronikowska M, Korcz A, Bronikowski M. The role of sports practice in young adolescent development of moral competence. Int J Environ Res Public Health. 2020;17:5324. https://doi.org/10.3390/ijerph17155324

[34] Bronikowska M, Korcz A, Krzysztoszek J, Bronikowski M. How years of sport training influence the level of moral competences of physical education and sport students. Biomed Res Int. 2019:Article ID 4313451. https://doi. org/10.1155/2019/4313451

[35] Koul R. Multiple motivational goals, values, and willingness to cheat. Int J Educ Res. 2012;56:1-9. https://doi. org/10.1016/j.ijer.2012.10.002 